\title{
Closure Plan for the Idaho National Laboratory Site's Materials and Fuels Complex Industrial Waste Ditch
}

June 2018

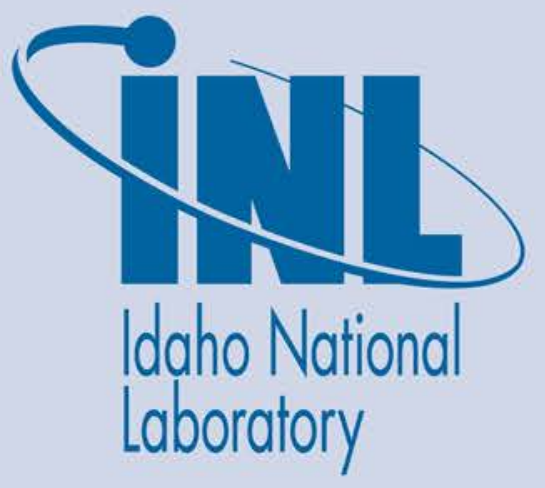

The INL is a U.S. Department of Energy National Laboratory operated by Battelle Energy Alliance 
INL/EXT-18-45500

\section{Closure Plan for the Idaho National Laboratory Site's Materials and Fuels Complex Industrial Waste Ditch}

June 2018

Idaho National Laboratory Idaho Falls, Idaho 83415

http://www.inl.gov

Prepared for the

U.S. Department of Energy

Office of Nuclear Energy, Science, and Technology

Under DOE Idaho Operations Office

Contract DE-AC07-05ID14517 


\section{ABSTRACT}

The Materials and Fuels Complex industrial waste system currently consists of the Industrial Waste Pond and Industrial Waste Ditch, associated piping, lift station, and flow meter. The Industrial Waste Pond and Industrial Waste Ditch, are land application sites permitted under Idaho Department of Environmental Quality Reuse Permit I-160-02, Modification 1. The Reuse Permit allows for 17 million gallons of industrial wastewater to be discharged to the land application sites. For Reuse Permit year 2017, approximately 7.569 million gallons were discharged to the land application sites, of which 1.649 million gallons were discharged to the Industrial Waste Ditch.

A project (MFC West Campus Utility Corridor project) is proposed to begin in the summer of 2018. The project will install a new utility corridor along the west and north sides of the Materials and Fuels Complex. As part of the design, it is proposed to reroute the wastewater currently discharged to the Industrial Waste Ditch into an underground pipe that would connect into the existing Industrial Waste Pipeline. A new flow meter and sampling location would be installed near the current discharge to the Industrial Waste Pond. This would allow for the combined wastewater streams to be monitored for flow and sampled for parameters required by the Reuse Permit.

In accordance with the Reuse Permit, this closure plan is being submitted to the Idaho Department of Environmental Quality for review and approval.

The closure plan includes:

- Brief background of the Materials and Fuels Complex.

- Site characteristics.

- Description of the Industrial Wastewater System.

- History of discharges to the Industrial Waste Ditch.

- Summary of the Comprehensive Environmental Response, Compensation, and Liability Act characterization, evaluation, and remediation of the Industrial Waste Ditch.

- Reuse Permit history.

- Contaminant concentrations in the effluent discharged to the Industrial Waste Ditch.

- Contaminant concentrations in cross gradient, downgradient, and background monitoring wells.

Based on the Comprehensive Environmental Response, Compensation, and Liability Act characterization and remediation of the Industrial Waste 
Ditch, low volumes and contaminant concentrations in the effluent subsequently discharged to the Industrial Waste Ditch, and contaminant concentrations at or near background levels in the monitoring wells, it is recommended that the Industrial Waste Ditch should be closed without further characterization. 


\section{CONTENTS}

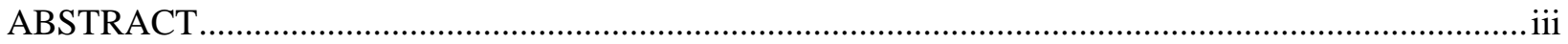

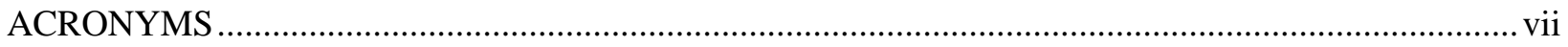

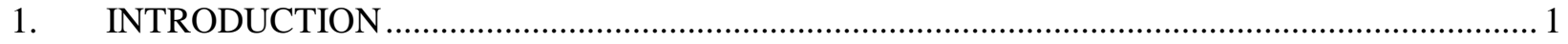

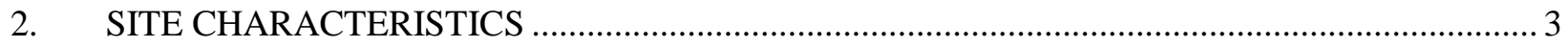

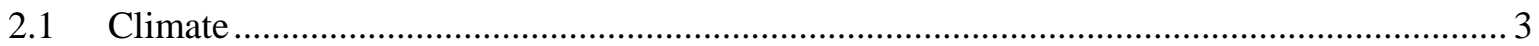

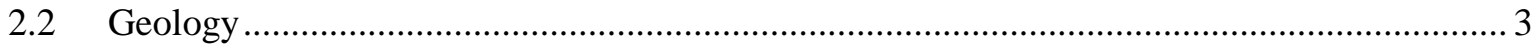

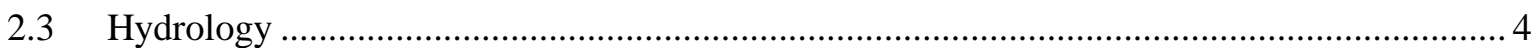

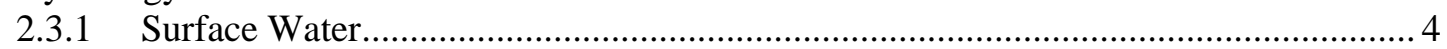

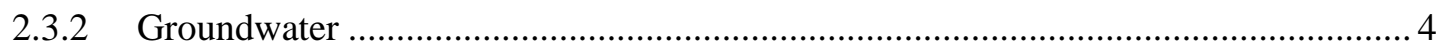

3. HISTORIC MFC INDUSTRIAL WASTEWATER SYSTEMS SUMMARY ................................ 5

4. DISCHARGE HISTORY TO THE MAIN COOLING TOWER BLOWDOWN DITCH............... 7

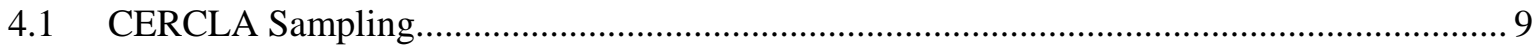

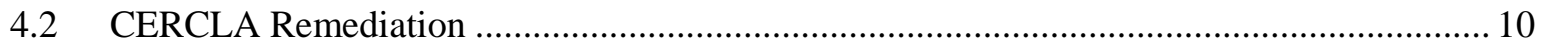

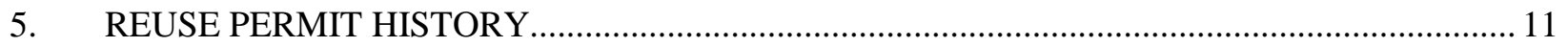

6. REUSE PERMITTED MFC INDUSTRIAL WASTEWATER SYSTEM .................................. 11

7. EFFLUENT CONTAMINANT CONCENTRATIONS DISCHARGED TO THE

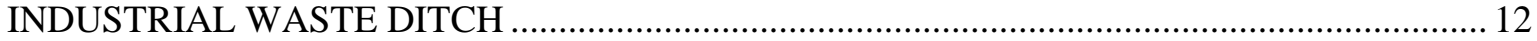

8. CONTAMINANT CONCENTRATIONS IN GROUNDWATER $\quad$............................................... 16

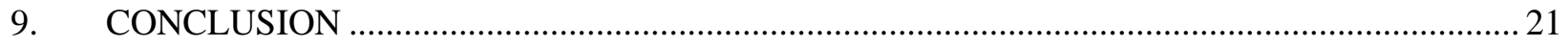

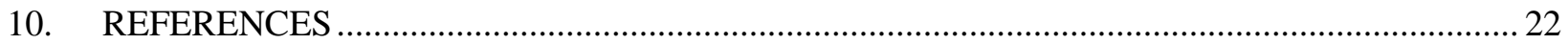

\section{FIGURES}

Figure 1. Materials and Fuels Complex Industrial Waste Pond, Industrial Waste Ditch, and monitoring wells.

Figure 2. Map showing proposed industrial waste line and CERCLA Institutional Control sites in relation to the Main Cooling Tower Blowdown Ditch.

Figure 3. Metals data for the effluent discharged to Industrial Waste Ditch. The limit shown in each graph is the DEQ Groundwater Quality Standard (IDAPA 58.01.11) for that metal. 
Figure 4. Non-metals data for samples collected from the effluent discharged to the Industrial Waste Ditch. The limit shown in each graph is the DEQ Groundwater Quality Standard (IDAPA 58.01.11) for the non-metal.

Figure 5. Metals data for groundwater monitoring well ANL-MON-A-011, ANL-MON-A-012, ANL-MON-A-013, and ANL-MON-A-014. The limit shown in each graph is the DEQ Groundwater Quality Standard (IDAPA 58.01.11) for that metal.

Figure 6. Non-metals data for groundwater monitoring well ANL-MON-A-011, ANL-MON-A012, ANL-MON-A-013, and ANL-MON-A-014. The limit shown in each graph is the DEQ Groundwater Quality Standard (IDAPA 58.01.11) for that constituent. 


\section{ACRONYMS}

ANL-W Argonne National Laboratory-W

BEA Battelle Energy Alliance, LLC

BLS below land surface

CERCLA Comprehensive Environmental Response, Compensation, and Liability Act

CFA Central Facilities Area

DEQ Idaho Department of Environmental Quality

DOE U.S. Department of Energy

DOE-ID U.S. Department of Energy Idaho Operations Office

EBR-II Experimental Breeder Reactor-II

ESRPA Eastern Snake River Plain Aquifer

INL Idaho National Laboratory

IWD Industrial Waste Ditch

IWP Industrial Waste Pond

MCTBD Main Cooling Tower Blowdown Ditch

MFC Materials and Fuels Complex

MG million gallons

PCS Primary Constituent Standard

RCRA Resource Conservation and Recovery Act

RO reverse osmosis

SCS Secondary Constituent Standard

TDS Total Dissolved Solids 


\section{Closure Plan for the Idaho National Laboratory Site's Materials and Fuels Complex}

\section{INTRODUCTION}

The Argonne National Laboratory-West (ANL-W) was established in the mid-1950s to research and develop nuclear reactors and fuel. The University of Chicago had operated facilities at the Idaho National Laboratory (INL) Site since its inception, until 2005, when operations were turned over to the INL. In 2005, ANL-W's name was changed to the Materials and Fuels Complex (MFC).

The INL Site is a government owned, contractor operated facility that is managed by the U.S. Department of Energy Idaho-Operations Office (DOE-ID). The INL Site includes several functional missions managed by separate contractors. These include clean-up, nuclear-energy research and technology development, developing and demonstrating national security technologies, and other science and technology activities. The current INL Management and Operating contractor, Battelle Energy Alliance, LLC (BEA), is responsible for the majority of MFC operations.

MFC missions are devoted mainly to research and development of nuclear technologies, nuclear environmental management, and space radioactive-power-source development. Currently, MFC consists of several major research facilities, in addition to a variety of operations, support, and office facilities discharging industrial wastewater to the Industrial Waste Pond (IWP) or Industrial Waste Ditch (IWD) system, as shown in Figure 1.

The IWP and IWD are permitted land application units by the Idaho Department of Environmental Quality (DEQ) under Reuse Permit I-160-02, Modification 1. The IWD is part of the Reuse Permit Management Unit MU-16001.

As part of the MFC West Campus Utility Corridor project, it is proposed to reroute the wastewater currently discharged to the IWD into an underground pipe that would connect into the existing Industrial Waste Pipeline, as shown in Figure 2. A new flow meter and sampling location will be installed near the outfall to the IWP. This would allow for the combined wastewater streams to be monitored for flow and sampled for parameters required by the Reuse Permit.

This closure plan is being submitted to DEQ for review and approval.

NOTE: The IWD is commonly referred to as Ditch C in Reuse Reports and the Reuse Permit. However, to reduce confusion with the designation of a Ditch $\mathrm{C}$ under the Comprehensive Environmental Response, Compensation, and Liability Act (CERCLA) investigation, Reuse Permit Ditch C will only be referred to as the IWD or the west Main Cooling Tower Blowdown Ditch (MCTBD) in this Plan. 


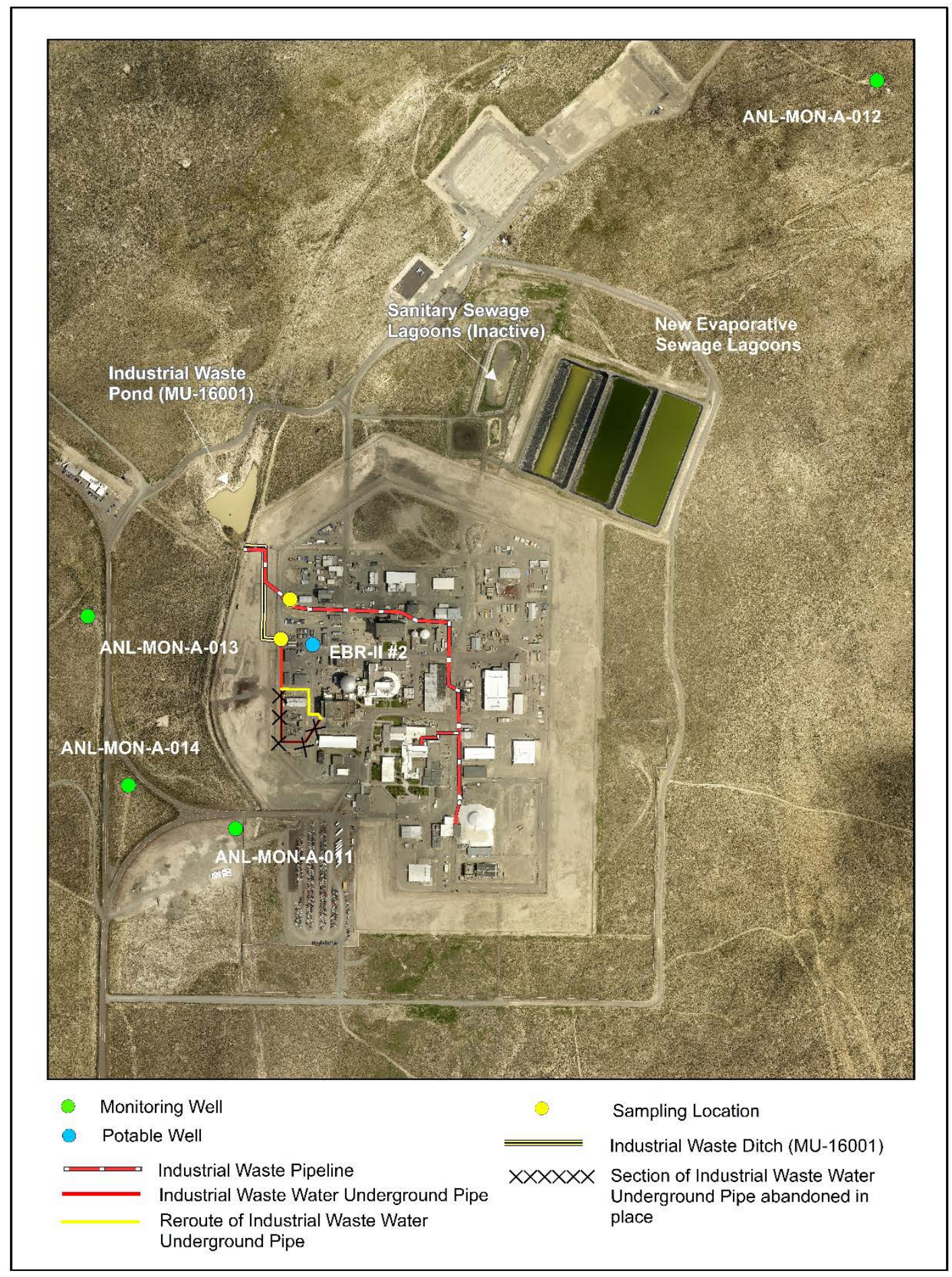

Figure 1. Materials and Fuels Complex Industrial Waste Pond, Industrial Waste Ditch, and monitoring wells. 


\section{SITE CHARACTERISTICS}

\subsection{Climate}

The INL Site is located in a large, relatively undisturbed expanse of sagebrush steppe.

The climate of the high desert environment of the INL Site is characterized by sparse precipitation (about $21.3 \mathrm{~cm} / \mathrm{yr}$ [8.40 in./yr]), warm summers (average daily temperature of $18.3^{\circ} \mathrm{C}\left[65.0^{\circ} \mathrm{F}\right]$ ), and cold winters (average daily temperature of $-7.4^{\circ} \mathrm{C}\left[18.7^{\circ} \mathrm{F}\right]$ ); based on observations at Central Facilities Area (CFA) from 1950 through 2016. The altitude, intermountain setting, and latitude of the INL Site combine to produce a semiarid climate. Prevailing weather patterns are from the southwest, moving up the Snake River Plain. Air masses, which gather moisture over the Pacific Ocean, traverse several hundred miles of mountainous terrain before reaching southeastern Idaho. Frequently, the result is dry air and little cloud cover. Solar heating can be intense, with extreme day-to-night temperature fluctuations (DOE/ID 2017).

\subsection{Geology}

MFC is within topographically closed watersheds; therefore, surficial materials are the result of upland erosion from the surrounding highlands or windblown loess. Low basalt ridges east of the facility rise as high as $100 \mathrm{ft}$ above the level of the plain. Surficial sediments cover most of the underlying basalt, except where pressure ridges form basalt outcrops. Thickness of these surficial sediments ranges from 0 to $14 \mathrm{ft}$. In general, the depths of the surface soils tend to increase from approximately $2 \mathrm{ft}$ deep on the east side of the facility to a depth of $14 \mathrm{ft}$ near the west side of the security fence.

The uppermost layer, from zero to several feet below land surface (BLS), consists of a light brown silty loam. The upper 1 to $2 \mathrm{ft}$ of this silty loam layer contains plant roots. This silty loam layer may also contain basalt fragments in areas where it directly overlies basalt. The lower layer is a sandy-silt (loess) that extends to the underlying basalt.

The subsurface geology is similar to that on the rest of the INL Site except for the lack of continuous sedimentary interbeds beneath the facility. The sedimentary interbeds appear to be discontinuous stringers, deposited in low areas on basalt surfaces. They are generally composed of calcareous silt, sand, or cinders. Rubble layers between individual basalt flows are composed of sand and gravel to boulder-sized material. The interbeds range in thickness from less than $1 \mathrm{in}$. to $15 \mathrm{ft}$. Aerially extensive interbeds have been identified above the regional water table, at approximately 400, 550, and $600 \mathrm{ft}$ BLS. The nature of these sedimentary interbeds and rubble zones does not appear to cause perching, but may retard the downward movement of water and produce preferred flow paths.

The thickness and texture of individual basalt lava flows are quite variable and range in thickness from 10 to $100 \mathrm{ft}$. The upper surfaces of the basalt flows are often irregular and contain many fractures and joints that may be filled with sediment (INL 2010). 


\subsection{Hydrology}

\subsubsection{Surface Water}

Three surface water sources, the Big Lost River, the Little Lost River, and Birch Creek, drain the mountain region to the north and west of the INL Site and intermittently flow onto INL Site. However, irrigation and hydropower diversions, and infiltration losses along the channel bed often deplete these sources before they reach INL. These are the only perennial natural water bodies associated with the INL Site; no perennial water bodies exist near MFC. The topography slopes from the MFC area toward Mud Lake; however, there are no perennial surface water bodies in this area. The primary surface-water features in the MFC area are the anthropogenic features (e.g., drainage canals, ditches, and discharge ponds) constructed for MFC operations and for the collection of intermittent surface runoff (INL 2010).

\subsubsection{Groundwater}

The Eastern Snake River Plain Aquifer (ESRPA) is a continuous body of groundwater underlying nearly all of the Eastern Snake River Plain. Depths to the water table from the INL land surface range from approximately $200 \mathrm{ft}$ in the northern part of the INL Site near Test Area North to more than $900 \mathrm{ft}$ in the south near the Radioactive Waste Management Complex. Aquifer boundaries are formed by contact of the aquifer with less permeable rocks at the margins of the plain. These boundaries correspond to the mountains on the west and north and to the Snake River on the east. The aquifer is approximately 200 miles long, 40 to 60 miles wide, and covers an area of approximately 9,600 square miles. It extends from Ashton, Idaho, northeast of the INL Site southwest to near Hagerman, Idaho (INL 2010).

Depth to the ESRPA at MFC is approximately $660 \mathrm{ft}$ based on recent water-level measurements. Recharge to the ESRPA near MFC occurs as snowmelt or rain. During rapid snowmelt in the spring, moderate recharge to the aquifer can occur. However, high evapotranspiration rates during the summer and early fall prevent significant infiltration from rainfall during this period. Because of the distance from the surrounding mountains and permanent surface water features (i.e., the Big Lost River), the ESRPA beneath MFC is relatively unaffected hydrologically by underflow or recharge from these sources. 


\section{HISTORIC MFC INDUSTRIAL WASTEWATER SYSTEMS SUMMARY}

Since the inception of ANL-W in the mid-50s, the number of facilities at this site has increased dramatically and the volume of water usage has changed over time. Ditches were constructed to convey the storm water and industrial wastewater flowing to the northwest toward the IWP. These main ditches (see Figure 2) were named as part of the CERCLA investigation as Ditch A, Ditch B, Ditch C, and the MCTBD, so they could be assessed for the contaminants of concern and current characteristics such as buried, dry, or under two feet of water. Under CERCLA, all these ditches were evaluated for human health and ecological risks. It was determined that these four ditches did not pose human health risks that required remediation. However, these risk calculations were performed prior to completion of the INL sitewide ecological risk assessment. Subsequently, ANL-W chose to complete remedial actions in Ditch A, part of Ditch B, and in the MCTBD to mitigate potential ecological risk. All of the remediation and removal actions were completed by 2004.

The following sections further discuss the MCTBD in detail. Note that the west portion of the MCTBD (see Figure 2) is what is known today as the IWD.

Because of minimal potential impact to the MCTBD, CERCLA Ditches A, B, and C are only briefly discussed in the following sections. 


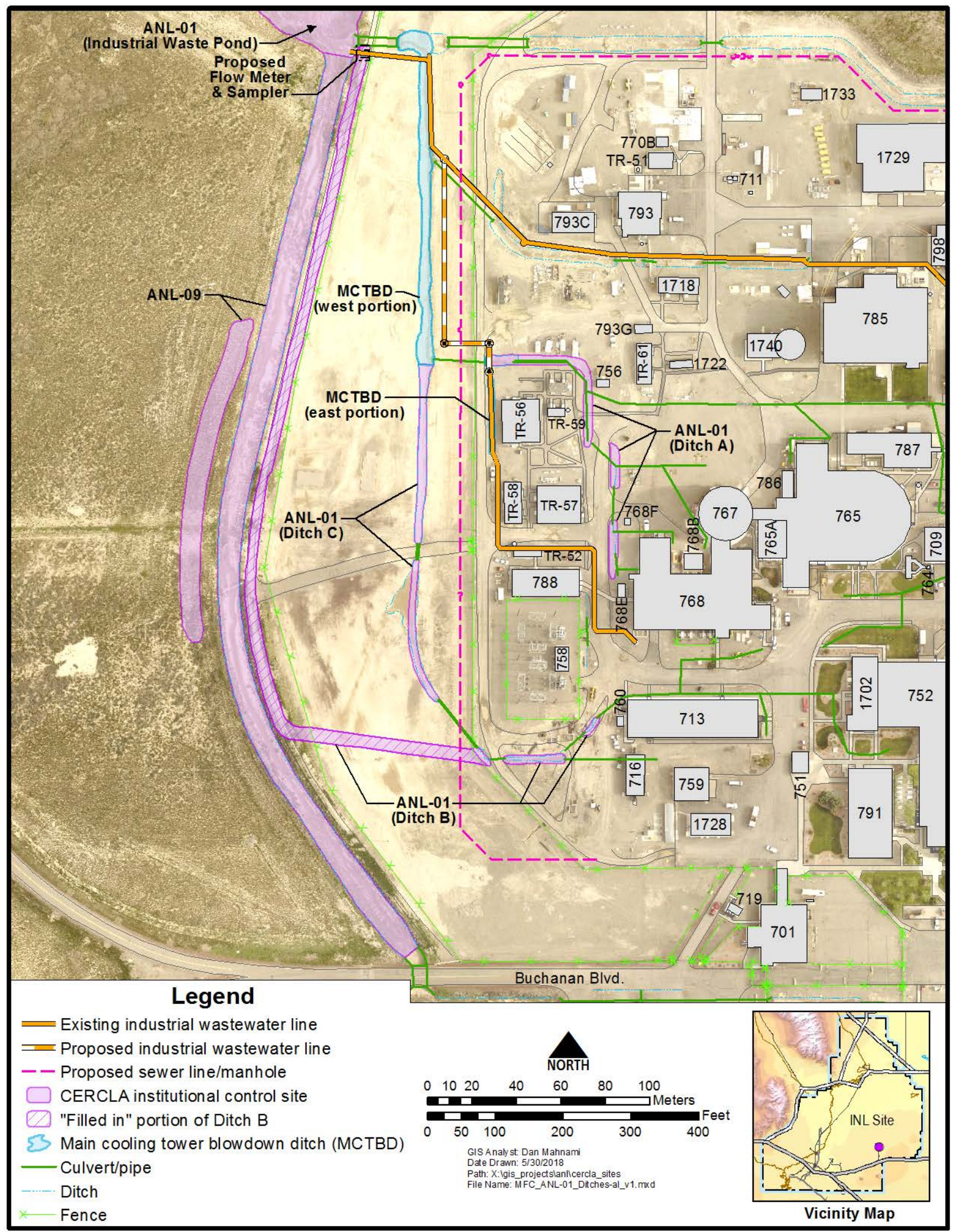

Figure 2. Map showing proposed industrial waste line and CERCLA Institutional Control sites in relation to the Main Cooling Tower Blowdown Ditch. 


\section{DISCHARGE HISTORY TO THE MAIN COOLING TOWER BLOWDOWN DITCH}

In 1999, under CERCLA, the MCTBD was divided into the east portion and the west portion (i.e., IWD) due to the differences in concentration of the contaminants of concern (chromium and mercury). The east portion had concentrations of chromium and mercury that were orders of magnitude higher than those found in the west portion. The west portion of the MCTBD is located between the inner and outer security fences. The following discussion contains historical discharge information pertinent to the east and west portions of the MCTBD (Figure 2):

\section{$\underline{1962 \text { to } 1996}$}

The MCTBD was originally installed in 1962 to transport the main cooling tower's catch basin effluent to the IWP. Until 1995, the MCTBD received all industrial liquid wastes from the main cooling tower at a loading rate of approximately 15 million gallons per year (ANL-W 1994 and ANL-W 1997). During this time, the waste discharged to the MCTBD was derived from two primary sources: cooling tower effluent (blowdown) and regeneration of the main cooling tower demineralizer columns.

Between 1962 and 1980, the main cooling tower blowdown contained low levels of hexavalent chromium (approximately 10-14 mg/L) that was used as a corrosion inhibitor in the cooling tower waters. Once released to the soil, hexavalent chromium was quickly reduced to trivalent chromium. In 1966, the hexavalent chromium was chemically reduced to trivalent chromium prior to discharge. In 1980, phosphate corrosion inhibitors replaced the chromiumbased corrosion inhibitors and no further hexavalent or trivalent chromium was discharged to the MCTBD blowdown. The main cooling tower water was routinely analyzed for chemical and physical properties (e.g., water chemistry, regeneration of demineralizers) inside building MFC768 (Power Plant). In January 1986, a pH measurement identified the pH of the effluent was 1.86. A temporary neutralization system was installed in March 1986, and a permanent neutralization tank was installed in October 1986 (ANL-W 1994).

Demineralizers (ion exchange columns) supplied purified water to several MFC buildings. The demineralizers were used to remove the ionic minerals $(\mathrm{Na}+, \mathrm{Ca}+, \mathrm{Cl}-$, etc.) from groundwater by running the water through columns containing cation and anion resins. These resins had to be regenerated periodically with acidic and basic solutions to remove the soluble metals adsorbed to the resins. The regeneration process occurred every three to four days that the Experimental Breeder Reactor-II (EBR-II) was operational, and contributed approximately 220,000 gallons/yr of liquid waste discharged to the MCTBD, which was comprised of approximately 960 gallons/yr sulfuric acid and 1,195 gallons/yr sodium hydroxide that did not chemically combine.

Approximately 8 gallons of chemicals were used annually in the water chemistry laboratory in building MFC-768-B that were discharged to the MCTBD. These chemicals, none of which are Resource Conservation Recovery Act (RCRA) listed, were used to measure water hardness and other parameters. These relatively small volumes of laboratory chemicals were diluted by the 15 million gallons (MG) of total liquids discharged annually (ANL-W 1994).

Ditches A, B, and C (see Figure 2), designated as parts of CERCLA unit ANL-01, discharged into the west portion of the MCTBD. Ditch C was created in 1978 when a portion of Ditch B was backfilled (see Figure 2). The discharge water going to Ditch B was rerouted by culvert under 
the security fence to Ditch C, which then drains to the west MCTBD (ANL-W 1998a). The water discharged to Ditch $\mathrm{C}$ was and remains the same as that in Ditch B. Ditches A, B, and C conveyed storm water and industrial wastewater from MFC-768 to the west MCTBD. These discharges ultimately ended up going to the IWP (DOE-ID 2011).

\section{6 to Present}

With the shutdown of the EBR-II reactor, the main cooling tower system was no longer needed and, shortly after, the demineralizer system was replaced with a reverse osmosis (RO) system. These changes reduced the discharge to the MCTBD from $15 \mathrm{MG} / \mathrm{yr}$ to approximately 1 to $1.5 \mathrm{MG} / \mathrm{yr}$. This RO system provides purified water to MFC-765 (Fuel Conditioning Facility), MFC-768 (Power Plant), MFC-785 (Hot Fuel Examination Facility), and MFC-793 (Sodium Components Maintenance Shop). The first two units of the RO system were installed in the mid1990s. The third RO unit was added in the late 1990s to meet the increasing demands. The demineralizer system was retained as a backup system.

A technical evaluation (TEV-2687) of the purified water system performed in 2016 determined that the old demineralizer system (except for the two mixed-bed columns) could be removed from service.

The two mixed-bed columns of the old demineralizer system were retained to be able to produce very high purity water from the RO units. Since the RO units have been in place, operations personnel indicate that the mixed-bed columns have not been used. The term mixedbed means that each column contains a homogenous mixture of cation and anion resins. If the mixed-bed columns are ever used, sulfuric acid would be used to regenerate the cation resin and sodium hydroxide would be used to regenerate the anion resin.

Wastewater transported to the MCTBD via the Industrial Waste Water Underground Pipe since 1996 consists of cooling water blowdown from a small auxiliary cooling tower located in MFC-768, intermittent RO effluent, and rinse water from a laboratory sink.

Ditches A, B, and C continue to discharge to the west MCTBD. Discharges from these ditches consists primarily of storm water. Industrial wastewater discharged to Ditch A is from overflow from the MFC-768 auxiliary cooling tower blowdown. This only occurs under upset conditions or when maintenance is performed on the system and the wastewater cannot drain to the Industrial Waste Water Underground Pipe.

The industrial wastewater discharge to Ditch B is boiler blowdown from the boiler located in building MFC-768. This discharge is approximately 10 to 20 gallons/week during the heating season and does not flow more than a couple of feet in the open portion of Ditch B.

Water treatment chemicals are used to prevent corrosion and scaling in the auxiliary cooling tower and boiler water systems in MFC-768. Examples of water treatment chemicals that have been or are currently used include sodium sulfite, sodium hydroxide, potassium hydroxide, sodium tolytriazole, sodium poly acrylate, chlorotolyltriazole sodium salt, and various amines (INL 2012).

Typically, wastewater in the west MCTBD seldom flows more than a few tens of feet past the Reuse Permit sampling point before it evaporates or infiltrates. Only when there is a significant storm water runoff event, does the water in the west MCTBD make it to the IWP. 


\subsection{CERCLA Sampling}

Soil samples were collected from the MCTBD as part of four different investigations occurring from 1987 to 1994. Samples were analyzed for volatile and semi-volatile organic compounds, PCBs, pesticides, herbicides, dioxin/furans, metals, and radionuclides (ANL-W 1996). In 1987, one soil sample was collected from the northern part of the ditch where a storm water discharge ditch flows into it. In 1988, four soil samples were collected from the different parts of the ditch. Three soil samples were collected from the west part of the ditch, while one sample was collected in the eastern portion of the ditch at the discharge point. In 1989, two soil samples were collected in the 145-foot interbed along the western portion of the ditch. Finally, in 1994, 35 samples were collected along the entire length of the ditch. The 1994 Sampling and Analysis Plan identified soil sample depths of 0 to $0.5 \mathrm{ft}, 3.5$ to $4 \mathrm{ft}$, and 9.5 to $10 \mathrm{ft}$ (ANL-W 1998a).

The screening process, including process knowledge and contaminant sampling in 1986, 1988, and 1991, identified beryllium, trivalent chromium, mercury, and silver as the only contaminants of concern. However, to further support this determination, soil samples were collected in 1994 (ANL-W 1994). The 1994 sampling event resulted in two metals trivalent chromium and mercury at levels high enough be retained as a contaminant of potential concern for the ecological receptors (ANL-W 1998a).

Chromium concentrations were the highest in the outfall from the cooling tower. But the entire length of the main cooling tower blowdown ditch had concentrations of chromium above the $95 \%$ upper confidence limit background concentration levels for the INL Site surface soils. The analysis performed on the chromium was for the total chromium analysis as described by the U.S. Environmental Protection Agency's Contract Laboratory Program analytical methods. The chromium was known to be almost exclusively in the trivalent form rather than the more toxic hexavalent form. However, to be conservative, the U.S. Department of Energy (DOE) assumed that $10 \%$ of the total chromium would be in the more toxic hexavalent form. The chromium concentrations decreased with increasing depth and with increasing distance downstream of the cooling tower outfall. The maximum chromium concentration was $2,200 \mathrm{mg} / \mathrm{kg}$ for the east MCTBD, with the upper confidence limit concentration of 1,306 mg/kg (ANL-W 1998a).

Soil samples were collected from Ditch A as part of two different investigations. Samples were collected in 1988 and again in 1994. Mercury was identified as a contaminant of concern for Ditch A (DOE-ID 2011).

Soil samples from Ditch B, including the filled in portion, were collected as part of three different investigations. Two different sets of samples from two different investigations were collected in 1988. Samples were also collected in 1994. Chromium and zinc were identified as contaminants of concern in the open portion of Ditch B (DOE-ID 2011).

Similar to Ditch B, soil samples were collected from Ditch C, twice in 1988 and once in 1994, all from separate investigations. Mercury was evaluated as a contaminant of potential concern in Ditch C. It was concluded that the mercury concentrations $(0.29 \mathrm{mg} / \mathrm{kg})$ in Ditch C soils did not pose any human health or ecological risks (ANL-W 1998b). No additional characterization or remediation was performed on Ditch C. 


\subsection{CERCLA Remediation}

Remediation for the MCTBD began in May 1999. The MCTBD was divided into two portions based on location as stated previously. The east portion of the MCTBD was located near the main cooling tower inside the MFC protection area. The west portion of the MCTBD, as seen in Figure 2, is located between the inner and outer security fences. Chromium and mercury were the contaminants of concern because of potential ecological risk. Contaminant concentrations varied spatially for the soil in the east and west portions by orders of magnitude. Because of the high contaminant concentrations in the east portion, it was determined that the selected remedy of phytoremediation would only work on the west MCTBD portion. Therefore, excavation and disposal was the selected remedy for the east portion and phytoremediation was the selected remedy for the west portion.

Phytoremediation actions were initiated at the west portion of the MCTBD in May 1999. Soil was initially removed from the area inside the two security fences and placed inside the MFC controlled area because the trees required for phytoremediation growing in the security area could have posed a concealment threat to MFC. Phytoremediation was initially estimated to take seven years to meet the remediation goals of $50 \mathrm{mg} / \mathrm{kg}$ for chromium and $0.74 \mathrm{mg} / \mathrm{kg}$ for mercury, respectively. The results after the first two years of implementation showed that phytoremediation using the hybrid willows and poplars was working better than expected and remediation goals could be met after four years. Phytoremediation activities continued in 2001 and 2002, and confirmation samples were collected in 2003. The Data Quality Assessment Report for the Post-Phytoremediation Characterization of ANL-W CERCLA Sites show the upper confidence limit values for chromium and mercury in the surface and subsurface soils, respectively. The upper confidence limits for surface samples and subsurface for chromium were $54.8 \mathrm{mg} / \mathrm{kg}$ and $61 \mathrm{mg} / \mathrm{kg}$, respectively, slightly above the remediation goal of $50 \mathrm{mg} / \mathrm{kg}$. The upper confidence limit for mercury in the surface and subsurface was $0.42 \mathrm{mg} / \mathrm{kg}$ and 0.37 $\mathrm{mg} / \mathrm{kg}$, respectively, both below the remediation goal of $0.74 \mathrm{mg} / \mathrm{kg}$. The remediated soil was subsequently removed from MFC and disposed at the CFA Landfill.

For Ditch A, phytoremediation to remove the mercury was initially chosen as the preferred remediation method and began in May 1999. Confirmation samples were collected in 2003 and showed that hotspots remained in the Ditch A soils. Therefore, the contingency remedy of excavation and disposal was used (DOE-ID 2011).

The remedy for the chromium and zinc in the open portion of Ditch B consisted of excavation and disposal. Soil was removed to the top of the basalt for both ditches and disposed to the CFA Landfill (DOE-ID 2011). The contaminants in the covered portion of Ditch B were screened from further concern since the pathway was eliminated when the area was backfilled with clean soils (ANL-W 1999).

All remedial action was completed by the end of 2004 (DOE-ID 2011). CERCLA Ditches A, $\mathrm{B}$, and $\mathrm{C}$ are still identified as part of the Institutional Control site ANL-01 (IWP and Associated Ditches). Institutional Controls at this site (see Figure 2) are scheduled to be terminated in 2028 when the cesium-137 in the IWP decays to releasable levels. There are no Institutional Control requirements for the MCTBD. 


\section{REUSE PERMIT HISTORY}

A Reuse Permit application for the MFC IWP was originally prepared and submitted to DEQ in January 1996. A Reuse Permit for the MFC IWP was not issued by DEQ at that time. On August 16, 2007, an updated Reuse Permit application was submitted (Stenzel 2007). The first Reuse Permit was issued on April 14, 2010 (Neher 2010), which included the IWD in addition to the IWP. Modification 1 of this permit occurred on June 21, 2012 (Neher 2012). This Reuse Permit expired on April 30, 2015; however, coverage under this permit continued until a new permit was issued. On October 28, 2014, a renewal application was submitted (Miller 2014) to DEQ. The current Reuse Permit was issued on January 26, 2017 (Neher 2017a), and Modification 1 to the Reuse Permit was issued on March 7, 2017 (Neher 2017b). The current permit expires on January 25, 2027.

\section{REUSE PERMITTED MFC INDUSTRIAL WASTEWATER SYSTEM}

The IWP is located near the northwest corner of the MFC. The IWP was first excavated in 1959 and has a design capacity of 285 MG at a maximum water depth of 13 feet. The IWP receives industrial wastewater from the Industrial Waste Pipeline, storm water runoff from MFC and immediate areas, and industrial wastewater and storm water from the IWD. Most of the industrial wastewater generated at MFC flows through collection piping to a lift station where it is pumped into the Industrial Waste Pipeline and discharged to the pond. A flow meter and composite sampler are located on the pipeline near the western boundary of MFC. The flow into the IWD is visually estimated on a weekly basis. The maximum hydraulic loading rate allowed by the permit for both discharges, IWP and IWD, is 17 MG/yr. For the 2017 Reuse Permit year, the estimated flow into the IWP was 5.92 MG and the estimated total volume of water discharged to the IWD was 1.65 MG.

Wastewater from the Industrial Waste Pipeline consists primarily of noncontact cooling water, boiler blowdown, cooling tower overflow, air washer (swamp cooler) flows, and steam condensate. Small amounts of industrial wastewater from the MFC facility process holdup tanks may also be discharged to the IWP system, once approved by the facility supervisor and environmental compliance staff.

Wastewater transported to the IWD via the Industrial Waste Water Underground Pipe consists of cooling water blowdown and intermittent RO effluent. The wastewater discharged to the IWD seldom flows more than a few tens of feet past the sampling point before it evaporates, infiltrates, or is taken up by plants (Miller 2018). 


\section{EFFLUENT CONTAMINANT CONCENTRATIONS DISCHARGED TO THE INDUSTRIAL WASTE DITCH}

Quarterly sampling of the effluent discharged into the IWD began in May 2010 with the issuance of the first Reuse Permit. Figure 3 shows the metals required to be sampled by the 2010 Reuse Permit. Limits shown in Figures 3 and 4 are the DEQ groundwater Primary Constituent Standard (PCS) or Secondary Constituent Standard (SCS, IDAPA 58.01.011) when available. The PCS and SCS values are shown for comparison purposes as they are not directly applicable to the IWD effluent requirements.

With the exception of iron and manganese, metal analytes had concentrations significantly lower than the applicable standard. Iron concentrations were typically below the SCS, with an occasional concentration above the standard. Manganese was also typically below the applicable SCS with the exception of samples collected on March 2, 2011, January 24, 2012, and August 8, 2012. Arsenic, barium, cadmium, chromium, lead, mercury, selenium, silver and zinc were consistently at or near the laboratory instrument's minimum detection levels.

The non-metals (see Figure 4) were typically well below the applicable PCS or SCS. The exception to this were the total dissolved solids (TDS) concentrations. The TDS concentrations were near the SCS. 
Industrial Waste Ditch

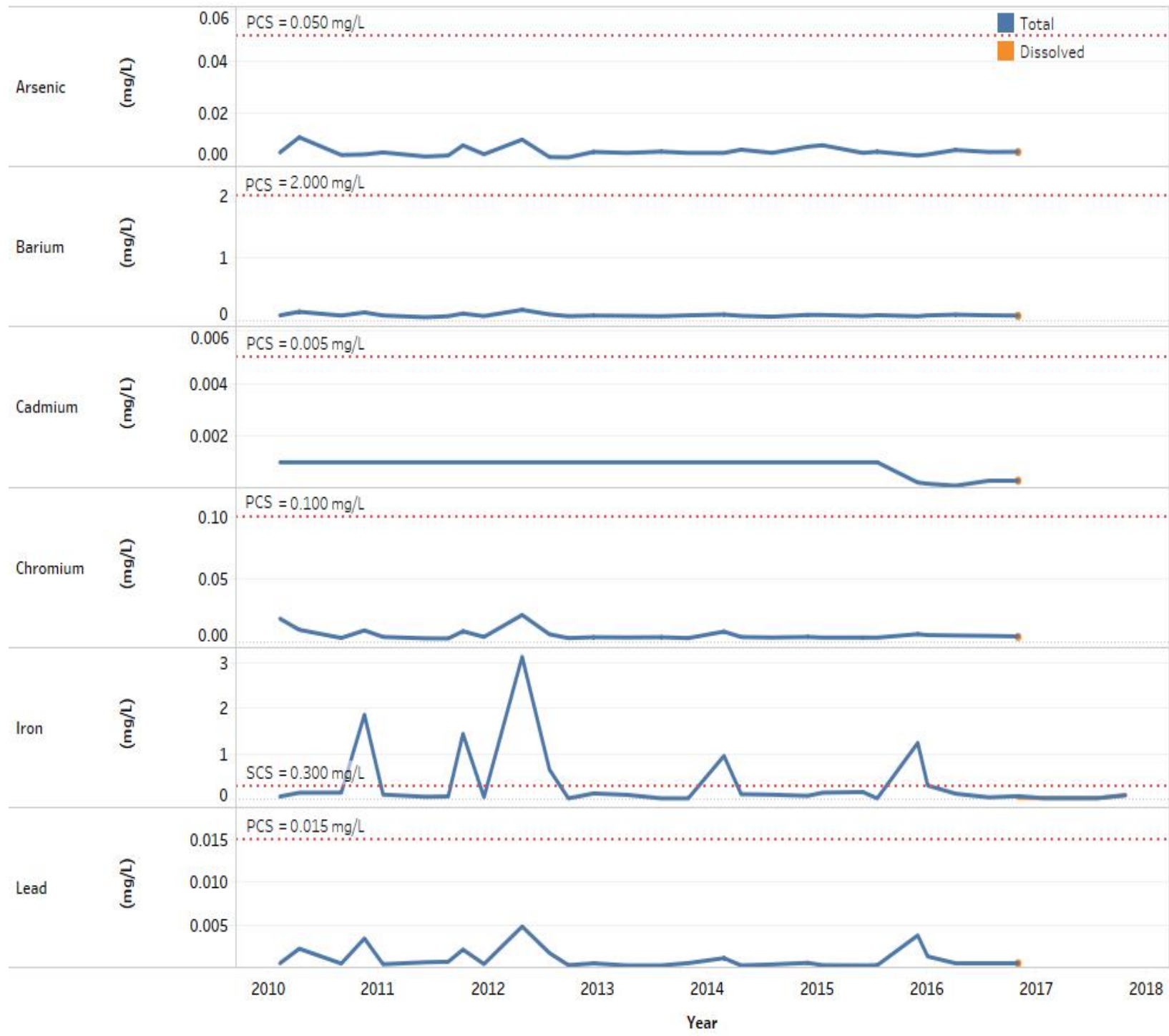

Figure 3. Metals data for the effluent discharged to Industrial Waste Ditch. The limit shown in each graph is the DEQ Groundwater Quality Standard (IDAPA 58.01.11) for that metal. 
Industrial Waste Ditch

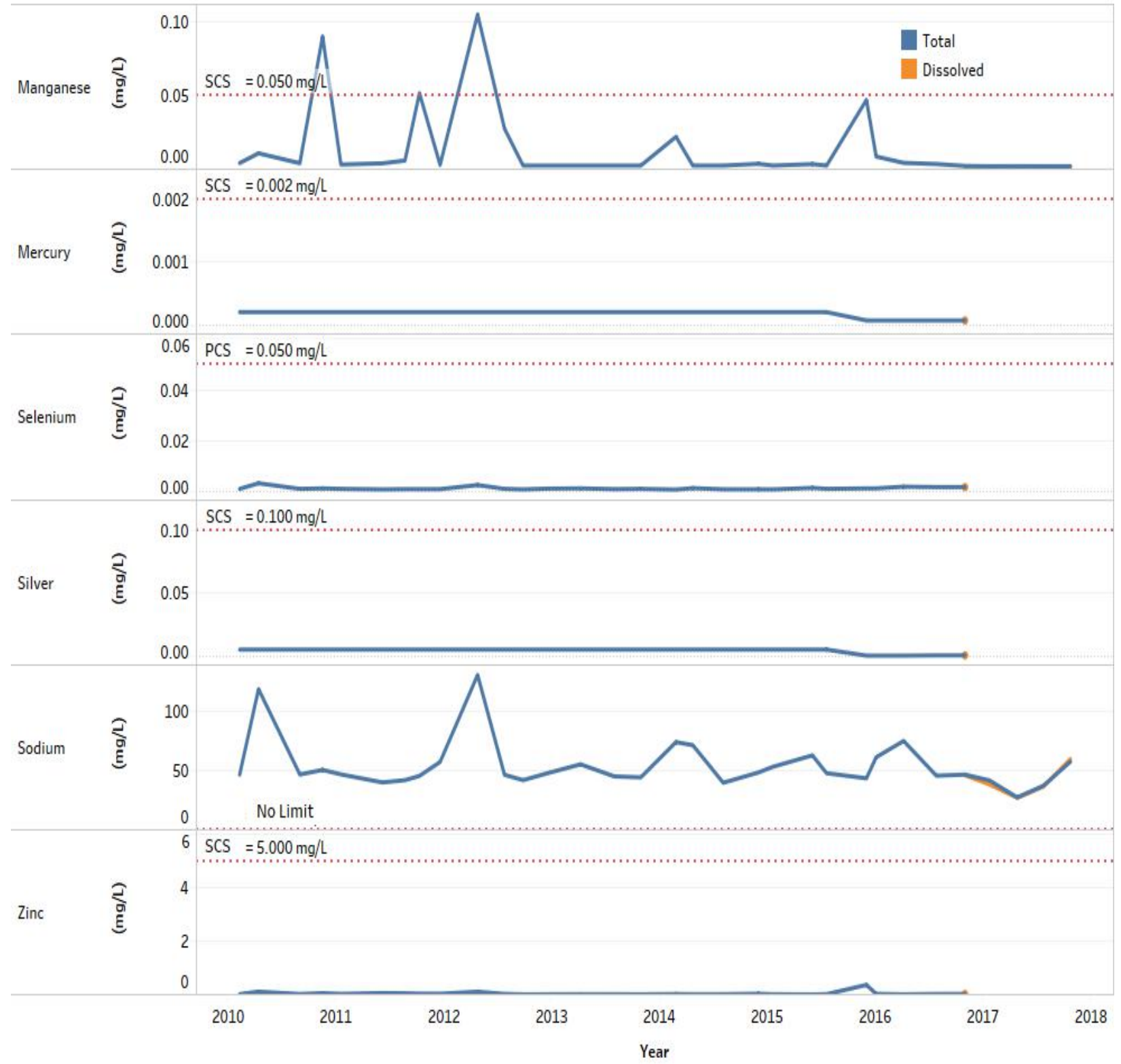

Figure 3. (cont.) 
Industrial Waste Ditch

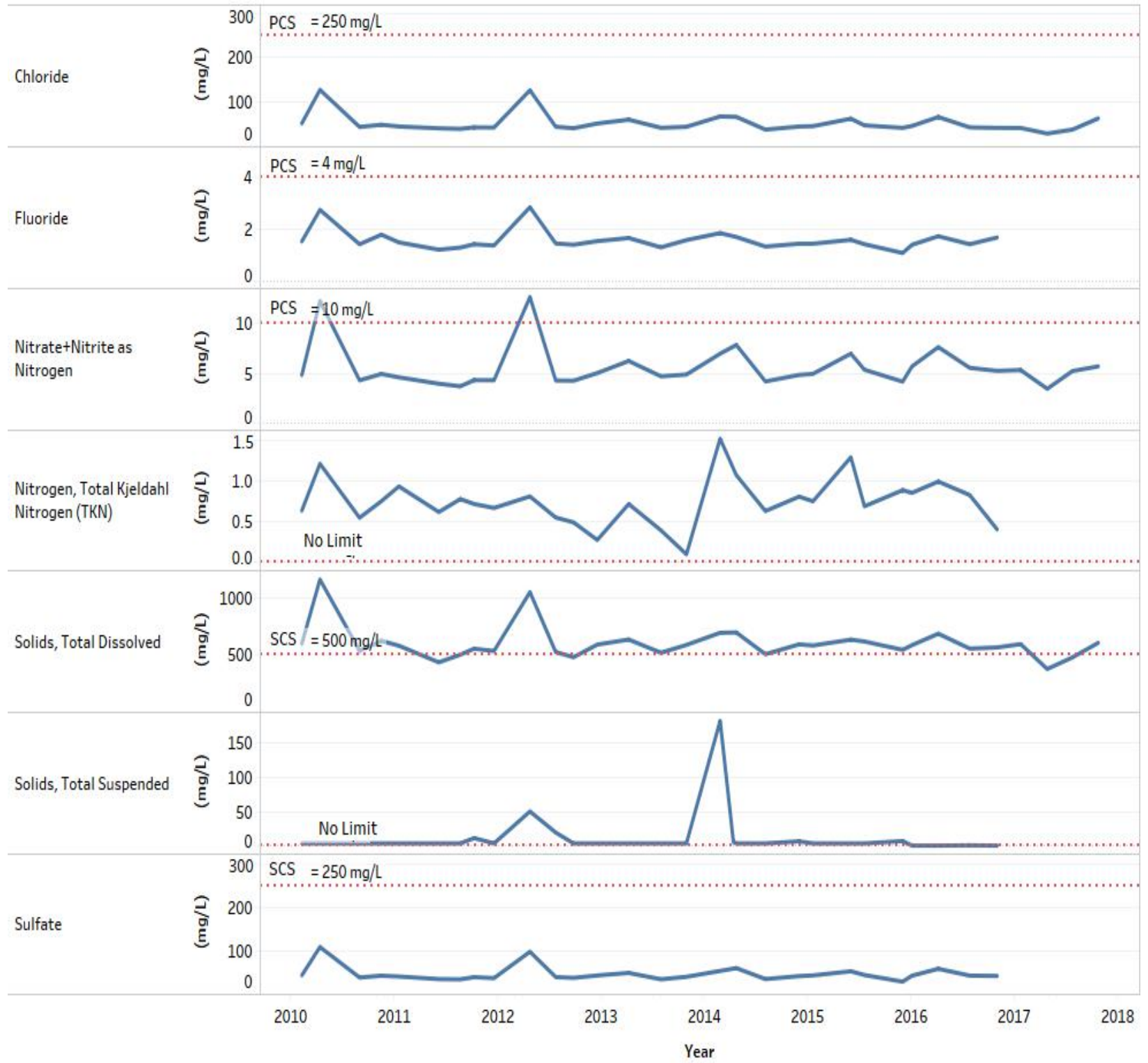

Figure 4. Non-metals data for samples collected from the effluent discharged to the Industrial Waste Ditch. The limit shown in each graph is the DEQ Groundwater Quality Standard (IDAPA 58.01.11) for the non-metal. 


\section{CONTAMINANT CONCENTRATIONS IN GROUNDWATER}

Historical groundwater data from April 1994 through September 2017 are presented in Figures 5 and 6. Sampling in accordance with the Reuse Permit began in May 2010. Wells ANLMON-A-012, ANL-MON-A-013, and ANL-MON-A-014 (see Figure 1) are wells required to be sampled under the Reuse Permit. Well ANL-MON-A-011 is sampled under CERCLA. Well ANL-MON-A-012 is an upgradient well in relation to the IWP and the IWD. The other three wells are considered cross gradient or downgradient wells.

In general, the metals concentrations in the cross gradient and downgradient wells are similar to the upgradient well. Figures 5 and 6 show the applicable PCS or SCS for comparison with the sample results. Calcium, cobalt, magnesium, nickel, potassium, sodium, tin, and vanadium do not have a PCS or SCS (see Figure 5). Arsenic, chromium, cobalt, copper, mercury, silver, thallium, tin, and zinc levels in all of the wells were typically at or near the laboratory instruments minimum detection level and significantly less than an applicable PCS or SCS.

The graph for antimony, from April 1994 to 2002, shows several sample results where the results were higher than the PCS. A review of the data shows that these concentrations are below the laboratory instrument's minimum detection level. Approximately $94 \%$ of the antimony results for all years sampled were below detection limits.

Of the metals, only iron had results that were routinely at or above the SCS $(0.3 \mathrm{mg} / \mathrm{L})$. Filtered sample results for iron were at or near the laboratory instruments minimum detection level and well below the SCS. The filtered sampled results are an indication the iron may be coming from corrosion of the carbon steel well casings. Video from May 2014 of wells ANLMON-A-012 and ANL-MON-A-13 showed corrosion of the carbon steel casing and a reddish buildup on the stainless steel screen (Miller 2016).

The non-metals (see Figure 6) concentrations in the cross gradient and downgradient wells are similar to the concentrations in the upgradient wells. The non-metal concentrations in all the wells are significantly lower than the applicable PCS or SCS. 


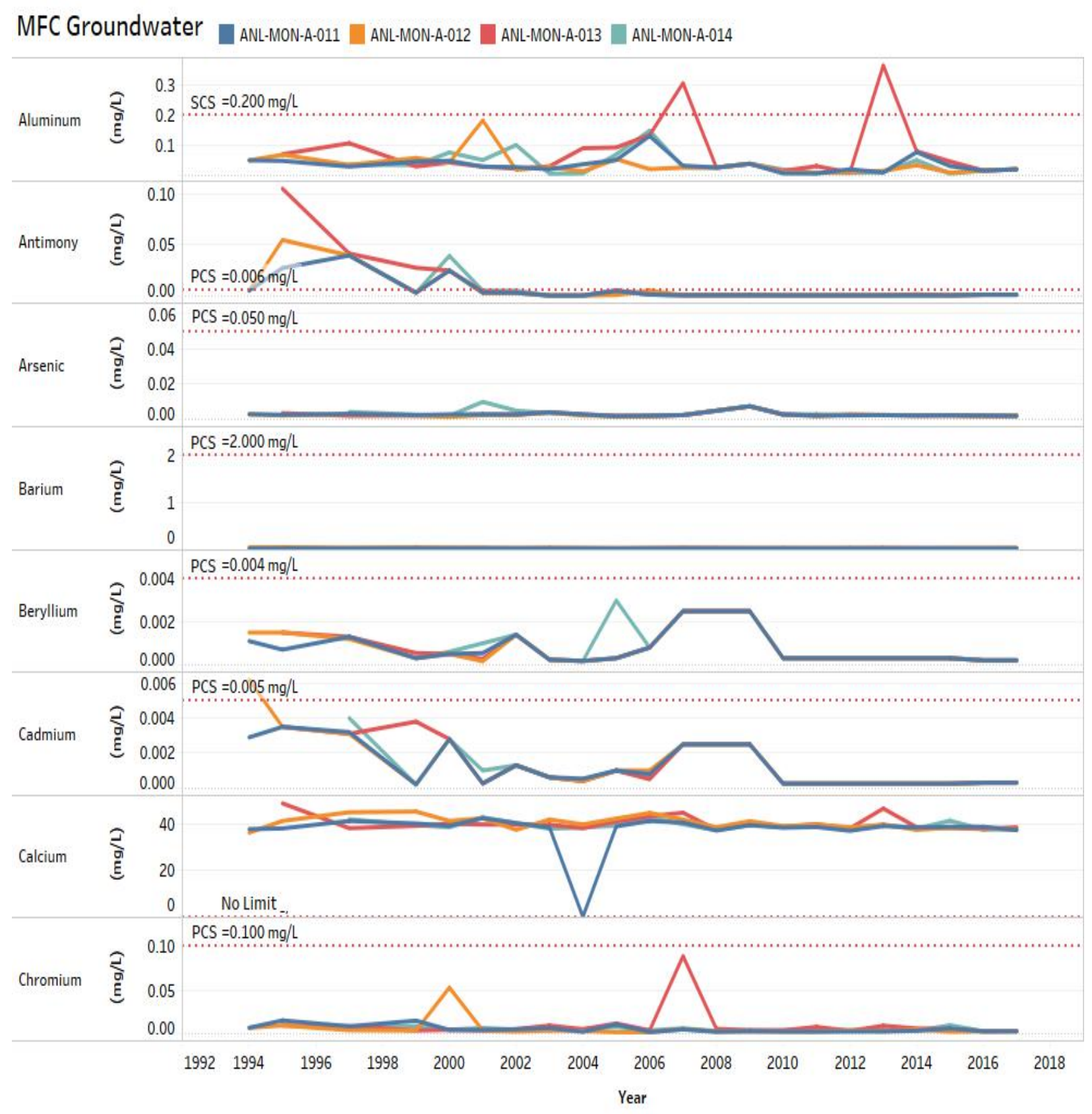

Figure 5. Metals data for groundwater monitoring well ANL-MON-A-011, ANL-MON-A-012, ANL-MON-A-013, and ANL-MON-A-014. The limit shown in each graph is the DEQ Groundwater Quality Standard (IDAPA 58.01.11) for that metal. 


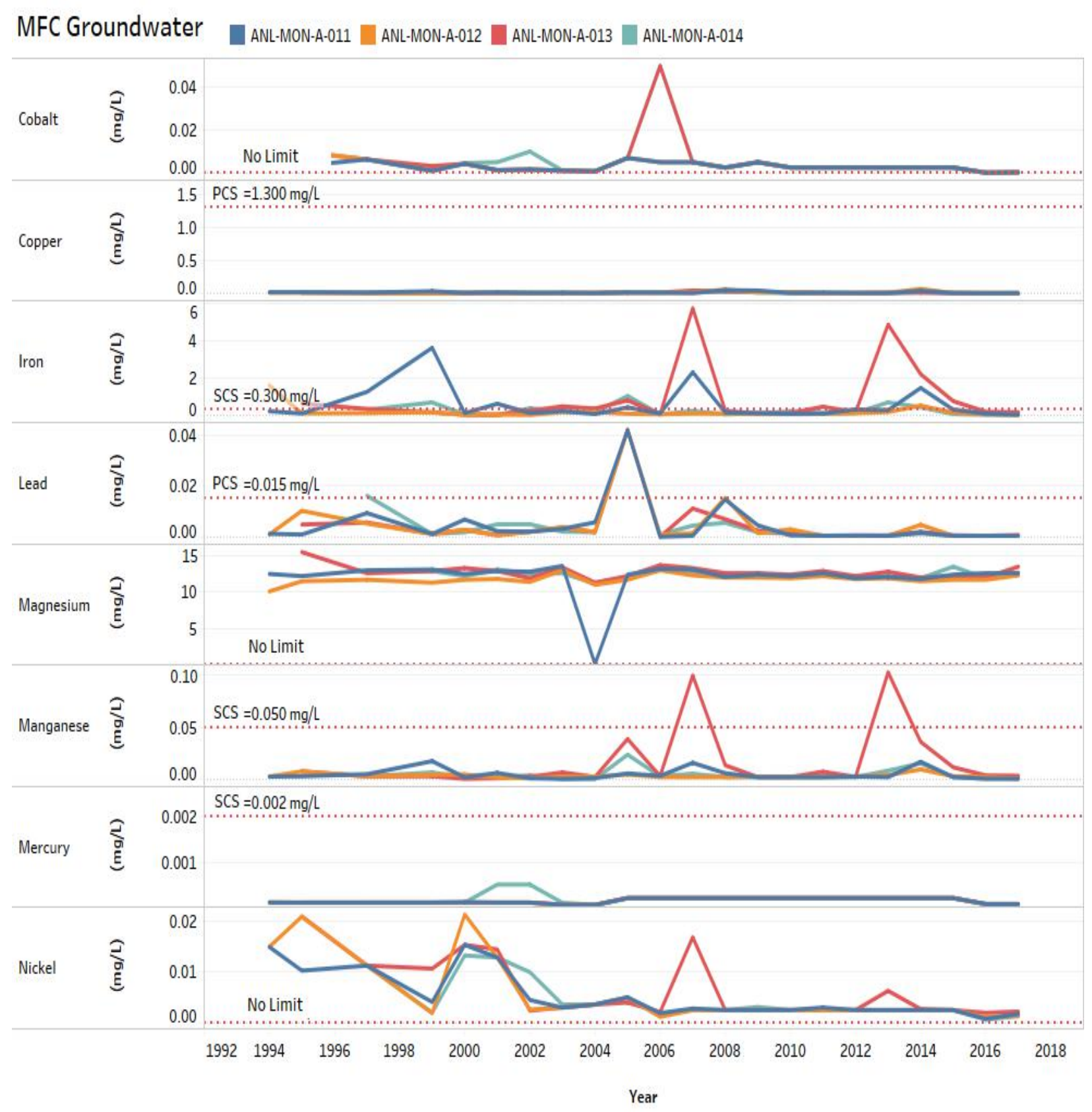

Figure 5. (cont.) 


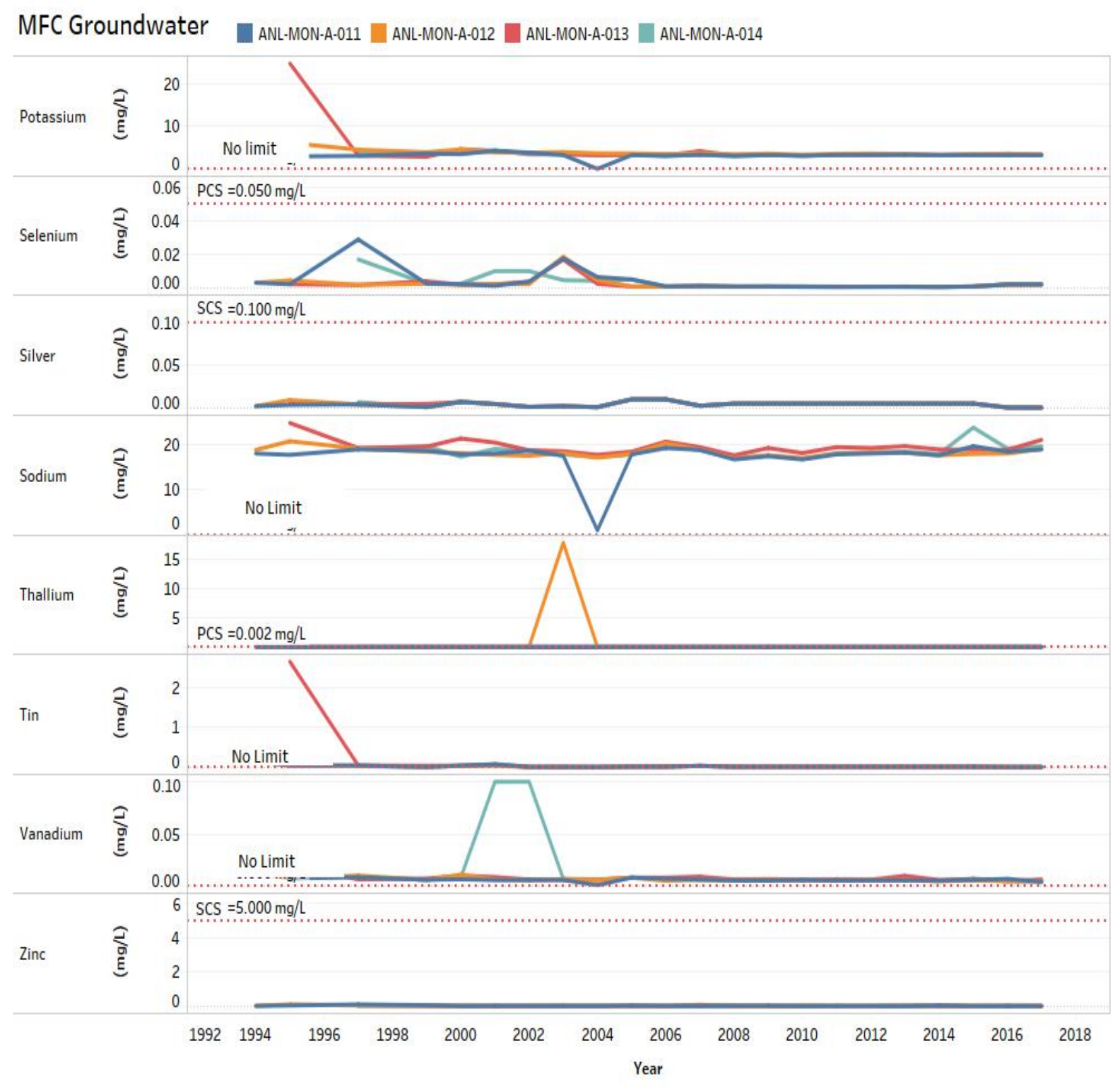

Figure 5. (cont.) 


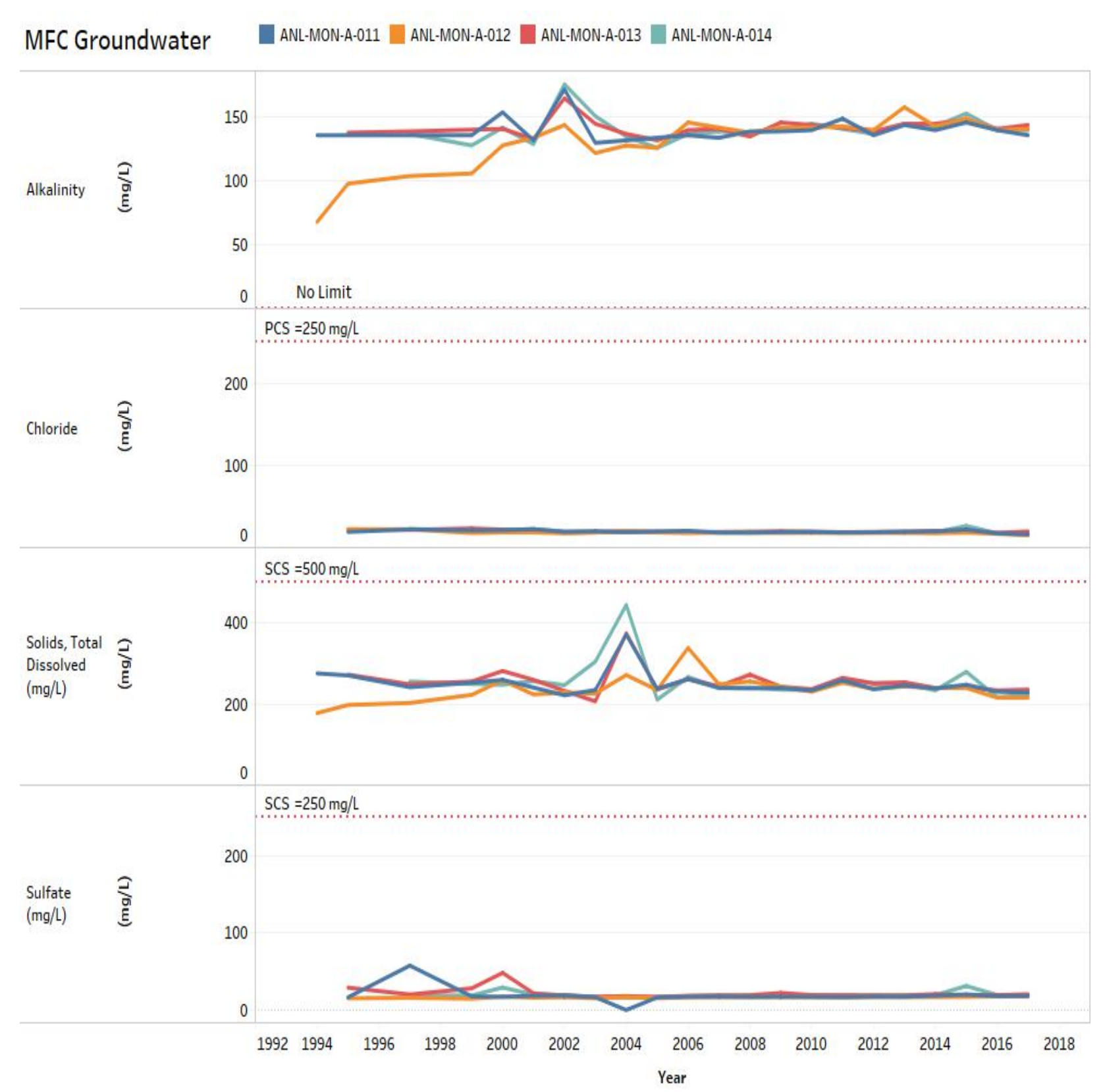

Figure 6. Non-metals data for groundwater monitoring well ANL-MON-A-011, ANL-MON-A012, ANL-MON-A-013, and ANL-MON-A-014. The limit shown in each graph is the DEQ Groundwater Quality Standard (IDAPA 58.01.11) for that constituent. 


\section{CONCLUSION}

The IWD (west MCTBD) was evaluated, characterized, and remediated under CERCLA. Samples from the IWD were collected in 1987, 1988, 1989, and 1994. Samples were analyzed for volatile and semi-volatile organic compounds, polychlorinated biphenals, pesticides, herbicides, dioxin/furans, metals, and radionuclides (ANL-W 1996).

Based on the sample results, only chromium and mercury were identified as contaminants of concern based on ecological receptors. The contaminants were from corrosion inhibitors added to the water for the Main Cooling Tower. A chromate-based corrosion inhibitor was added to the cooling water from 1962 to July 1980. Large volumes of sulfuric acid and sodium hydroxide were used to regenerate the demineralizer ion exchange columns. Mercury was an expected contaminant in the sulfuric acid.

In 1995, the Main Cooling Tower was no longer needed and removed from service. In 1996, an RO system was installed that was used in place of the old demineralizer system. These two changes resulted in a significant decrease in the volume of wastewater and contaminants discharged to the IWD.

Remediation under CERCLA of the IWD began in 1999 when soil was removed from the IWD and placed inside the MFC. The selected remedy was phytoremediation using hybrid willows and poplars. The remedy was expected to take seven years but based on sample results, it was found that the remediation would actually only take four years. Following the phytoremediation, the soil was taken to the CFA Landfill for final disposal. Remediation of the IWD was considered complete in 2004.

Ditches A and B that discharge into the IWD were also remediated. The final remediation for both of these ditches consisted of removing the soil down to the top of the basalt and disposing of it at the CFA Landfill. CERCLA Ditch C did not require remediation.

No hazardous or radioactive constituents have been discharged to the IWD since the remediation was completed. Effluent data, beginning in 2010, shows the minimal concentration of contaminants discharged to the IWD. In addition, the groundwater monitoring wells that are cross gradient or downgradient show contaminant levels similar to the concentrations in the upgradient well.

Based on the information provided in this closure plan, it is proposed that the IWD be closed under the requirements in the Reuse Permit and IDAPA 58.01.17 (Recycled Water Rules) without additional sampling and characterization. 


\section{REFERENCES}

ANL-W, 1994, "Sampling and Analysis Plan for Operable Units 9-01, 9-03, and 9-04 at the Idaho National Engineering Laboratory: Track 1 Sampling, Track 2 Sampling, and RI/FS Screening Sample Collection,” W7500-4234-NP-01, Argonne National Laboratory-West, November 1994.

ANL-W, 1996, “Comprehensive RI/FS Final Work Plan for Waste Area Group 9,” W75000000-ES-03, Argonne National Laboratory-West, July 29, 1996.

ANL-W, 1997, “Comprehensive Remedial Investigation/Feasibility Study for Argonne National Laboratory-West Operable Unit 9-04 at the Idaho National Engineering and Environmental Laboratory (Final),” W7500-0000-ES-02, Argonne National Laboratory-West, December 1997.

ANL-W, 1998a, "Final Record of Decision Argonne National Laboratory-West, Operable Unit 9-04, Idaho National Engineering and Environmental Laboratory,” W7500-000-ES-04, U. S. Department of Energy Chicago Operations Office; Idaho Department of Health and Welfare, Division of Environmental Quality, September 1998.

ANL-W, 1998b, "Remedial Design/Remedial Action Scope of Work for Waste Area Group 9, at the Idaho National Engineering Laboratory,” W7500-0549-ES-01, December 8, 1998.

ANL-W, 1999, “Final Remedial Design,” W7500-0550-ES-00, U. S. Department of Energy Chicago Operations Office; Idaho Department of Health and Welfare, Division of Environmental Quality, October 1999.

DOE/ID, September 2017, “Idaho National Laboratory Site Environmental Report Calendar Year 2017,” DOE/ID-12082(17).

DOE-ID, January 2011, "Five-Year Review of CERCLA Response Actions at the Idaho National Laboratory Site-Fiscal Years 2005-2009,” DOE/ID-11429, Rev. 0.

INL, December 2010, "Idaho National Laboratory Materials and Fuels Complex Natural Phenomena Hazards Flood Assessment,” INL-10-20572.

INL, August 30, 2012, “Plant Cooling Water Treatment,” PS-OI-25.

Miller, T. A., INL, to E. Neher, DEQ, October 28, 2014, “Transmittal of Idaho National Laboratory Recycled Water Reuse Permit Renewal Application for the Materials and Fuels Complex Industrial Waste Ditch and Industrial Waste Pond and Application Forms,” CCN 234270.

Miller, T. A., INL, to G. Eager, DEQ, February 25, 2016, “2015 Annual Industrial Wastewater Reuse Report and Groundwater Radiological Monitoring Results Report for Idaho National Laboratory Site's Materials and Fuels Complex Industrial Waste Ditch and Industrial Waste Pond,” CCN 237488.

Miller, T. A., INL, to G. Eager, DEQ, February 26, 2018, “2017 Annual Industrial Wastewater Reuse Report and Groundwater Radiological Monitoring Results for Idaho National 
Laboratory Site's Materials and Fuels Complex Industrial Waste Ditch and Industrial Waste Pond," CCN 242021.

Neher, E., DEQ, to W. F. Hamel, DOE-ID, and D. Coburn, INL, April 14, 2010, "Materials and Fuels Complex (MFC) Industrial Waste Ditch (IWD) and Industrial Waste Pond (IWP), Industrial Wastewater Reuse Permit No. LA-000160-01,” CCN 220726.

Neher, E., IDEQ, to W. Hamel, DOE-ID and C. Melbihess, INL, June 21, 2012, "WRU-I-160-01 INL MFC Industrial Waste Pond, Permit Modification 1 (formerly LA-000160-01),” CCN 227704.

Neher, E., IDEQ, to R. Boston, DOE-ID and T. A. Miller, INL, January 26, 2017a, "WRU-I160-01 INL MFC Industrial Waste Pond, Permit Modification 1 (formerly LA-000160-01),” CCN 239767.

Neher, E., IDEQ, to R. Boston, DOE-ID and T. A. Miller, INL, March 7, 2017b, "Idaho National Laboratory (INL) Materials and Fuels Complex (MFC) Industrial Waste Ditch and Pond, Reuse Permit I-160-02, Modification 1,” CCN 240106.

Stenzel, J. A., INL, to T. Rackow, DEQ, August 16, 2007, “Transmittal of the Wastewater Reuse Permit Application for Wastewater Land Treatment at the Materials and Fuels Complex Industrial Waste Pond,” CCN 210769.

TEV-2687, April 6, 2016, "Evaluation to Remove Standby Demineralized Water Components.” 